\title{
PENGARUH METODE PEMBERIAN RANSUM PADA SIANG DAN MALAM HARI TERHADAP RESPON FISIOLOGIS AYAM JANTAN TIPE MEDIUM DI KANDANG POSTAL
}

\author{
The Effect of Giving Rations Method During the Day and Night on the Physiological Response of \\ Medium Type Roosters in Postal Cage.
}

\author{
Evelline Dhea Monica Wijaya, Sri Suharyati, Khaira Nova, Dian Septinova \\ Departement of Animal Husbandry, Faculty of Agriculture, University of Lampung \\ Jl. Prof.Dr. Soemantri Brojonegoro No.1 Gedong Meneng Bandar Lampung 35145 \\ e-mail: evellinedmw@gmail.com
}

\begin{abstract}
This study aimed to determine the effect of the method of giving rations during the day and night on the physiological response (respiratory rate, rectal temperature, and heart rate) of medium type roosters in postal cages and to determine the effect of the best day and night ration methods on physiological response of medium type rooster in postal cage. This study used a Completely Randomized Design (CRD), consisting of three treatments with six replications, those were P1: 30\% day and 70\% night ration; $\mathrm{P} 2: 50 \%$ day and 50\% night ration; P3: 70\% day and 30\% night ration. The chicken used was male Lohman strain medium type of 144 chickens. The resulting data were analyzed with variance at $5 \%$ level. The results showed that the influence of day and night administration method was not different $(\mathrm{P}>0.05)$ on the frequency of breath (51.73 to $55.27 \mathrm{Times} / \mathrm{min})$, rectal temperature $\left(41.13\right.$ to $\left.41.16^{\circ} \mathrm{C}\right)$, and heart rate frequency $(421.2$ to 434.7 times/minute).
\end{abstract}

Keywords: Day and night rationing, Medium type rooster, Physiological response, Postal cage

\begin{abstract}
ABSTRAK
Penelitian ini bertujuan untuk mengetahui pengaruh metode pemberian ransum pada siang dan malam hari terhadap respon fisiologis (frekuensi pernapasan, suhu rektal, dan frekuensi denyut jantung) ayam jantan tipe medium di kandang postal, serta mengetahui pengaruh metode pemberian ransum yang terbaik pada siang dan malam hari terhadap respon fisiologis ayam jantan tipe medium di kandang postal. Penelitian ini menggunakan Rancangan Acak Lengkap (RAL) yang terdiri atas tiga perlakuan dengan enam ulangan yaitu pemberian ransum 30\% siang dan 70\% malam (P1), 50\% siang dan 50\% malam (P2), dan 70\% siang dan $30 \%$ malam (P3). Ayam yang digunakan adalah ayam jantan tipe medium strain Lohman sebanyak 144 ekor. Data yang dihasilkan dianalisis dengan sidik ragam pada taraf 5\%. Hasil penelitian menunjukkan pengaruh metode pemberian ransum siang dan malam hari tidak berbeda nyata $(\mathrm{P}>0,05)$ terhadap frekuensi pernapanasan $\left(51,73-55,27 \mathrm{kali} /\right.$ menit), suhu rektal $\left(41,13-41,16^{\circ} \mathrm{C}\right)$, dan frekuensi denyut jantung $(421,2-$ $434,7 \mathrm{kali} / \mathrm{menit})$.
\end{abstract}

Kata kunci: Ayam jantan tipe medium, Kandang postal, Persentase ransum siang dan malam hari, Respon fisiologis.

\section{PENDAHULUAN}

Daging ayam merupakan salah satu sumber protein hewani yang cukup digemari masyarakat. Harga daging ayam relatif murah jika dibandingkan dengan daging ternak lain, daging ayam juga mudah didapat dan memiliki kadar protein tinggi. Selama ini daging ayam yang dikonsumsi berasal dari broiler dan ayam kampung. Selain kedua sumber tersebut, alternatif daging sebenarnya dapat pula diperoleh dari ayam jantan tipe medium.
Ayam jantan tipe medium merupakan hasil sampingan usaha penetasan ayam petelur yang tidak diharapkan karena hanya ayam betina yang dipasarkan untuk dimanfaatkan produksi telurnya. Menurut Riyanti (1995), ayam jantan tipe medium mempunyai bentuk tubuh dan kadar lemak yang menyerupai ayam kampung sehingga dapat digunakan untuk memenuhi kebutuhan konsumen yang terbiasa menyukai ayam yang kadar lemaknya cenderung seperti ayam kampung.

Produktivitas yang dimiliki oleh ayam jantan tipe medium akan mencapai titik optimal 
apabila disertai manajemen yang baik. Salah satu hal yang perlu diperhatikan dalam usaha meningkatkan produktivitas ini adalah melalui manajemen ransum. Manajemen ransum yang meliputi jenis ransum, jumlah ransum, frekuensi ransum dan bentuk ransum. Perbaikan manajemen khususnya untuk mengatasi masalah pemberian ransum dengan memperhatikan faktor lingkungan. Tingginya suhu lingkungan di Indonesia merupakan salah satu masalah dalam pencapaian performa ayam yang optimal karena akan mempengaruhi konsumsi ransum (feed intake).

Perbedaan suhu antara siang dan malam hari cukup tinggi yaitu berkisar antara $3-5^{\circ} \mathrm{C}$ dengan kisaran suhu harian $26-32^{\circ} \mathrm{C}$ (Aksi Agraris Kansius, 2003). Pada pagi hari suhu lingkungan masih nyaman, lalu meningkat dan terus terasa sangat panas pada pukul 11.00-14.00 siang, selanjutnya menurun menjadi nyaman kembali pada sore dan malam hari (Amrullah, 2003). Pada siang hari, suhu lingkungan tinggi (panas) mengakibatkan ayam akan banyak mengonsumsi air minum untuk mengimbangi terjadinya penguapan sebagai proses pelepasan panas dalam tubuh yang akan mengurangi konsumsi ransum agar produksi panas dalam tubuhnya tidak semakin tinggi. Pemberian ransum pada suhu lingkungan tinggi perlu diatasi dengan mengurangi proporsi pemberian ransum pada siang hari dan mengoptimalkan pemberian ransum pada malam hari yang memiliki suhu lingkungan yang lebih sejuk dan dingin.

Pemberian ransum yang lebih banyak pada siang hari ini merupakan pemberian ransum yang kurang efisien karena unggas akan mengalami stres tambahan karena panas metabolisme di dalam tubuhnya setelah mengkonsumsi ransum yang diberikan. Suhu yang tinggi dapat mengganggu fungsi fisiologis dari organ-organ pernapasan dan peredaran darah. Hal ini dapat mempengaruhi tingkat konsumsi ransum, air minum, konversi ransum, dan pertumbuhan ternak. Manajemen pemberian ransum dengan jumlah sedikit di siang hari dan porsi yang lebih besar pada malam hari dapat menghindari potensi stres pada ayam. Oleh sebab itu, metode pemberian ransum pada siang dan malam hari diharapkan berpengaruh terhadap respon fisiologis ayam jantan tipe medium di kandang postal.

\section{MATERI DAN METODE}

Penelitian ini dilaksanakan pada 30 Agustus-18 Oktober 2018 selama 7 minggu, di kandang postal, Laboratorium Terpadu, Fakultas Pertanian, Universitas Lampung.

\section{Materi}

Alat yang digunakan dalam penelitian ini meliputi peralatan pemeliharaan ayam, peralatan pengambilan data (termometer, stetoskop, stopwatch, alat tulis). Bahan yang digunakan dalam penelitian ini adalah ayam jantan tipe medium dengan ransum (BR1) PT Japfa Comfeed.

\section{Metode}

\section{Rancangan Percobaan}

Penelitian ini dilakukan secara eksperimental menggunakan Rancangan Acak Lengkap (RAL) dengan 3 perlakuan dan 6 ulangan. Perlakuan yang diberikan antara lain pemberian ransum $30 \%$ siang dan $70 \%$ malam (P1), 50\% siang dan 50\% malam (P2), dan $70 \%$ siang dan $30 \%$ malam $(\mathrm{P} 3)$.

\section{Peubah yang Diamati}

\section{a. Frekuensi Pernapasan (per menit)}

Frekuensi pernapasan dihitung dengan cara menghitung pergerakan thorax atau mengamati kembang kempisnya perut atau dengan mengamati pergerakan dengan membuka dan menutupnya mulut selama 1 menit (Yousef, 1985).

\section{b. Frekuensi Denyut Jantung (per menit)}

Frekuensi denyut jantung diperoleh dengan cara menempelkan stetoskop pada bagian dada kiri broiler, sehingga terdengar denyut jantungnya yang dihitung selama 1 menit (Hartono et al., 2002).

\section{c. Suhu Rektal $\left({ }^{\circ} \mathrm{C}\right)$}

Temperatur rektal diperoleh dengan cara memasukkan thermometer digital ke dalam rektal ayam (Hartono et al., 2002). Termometer dimasukkan ke dalam rektal ayam sedalam $\pm 1 / 3$ bagian termometer dan hingga berbunyi.

\section{Analisis Data}

Data yang diperoleh kemudian dianalisis dengan Analisis of Variance (ANOVA) pada taraf $5 \%$. 


\section{HASIL DAN PEMBAHASAN}

\section{Pengaruh Perlakuan terhadap Frekuensi Pernapasan Ayam Jantan Tipe Medium}

Hasil penelitian menunjukkan bahwa rata-rata frekuensi pernapasan ayam jantan tipe medium pada masing-masing perlakuan dapat dilihat pada Tabel 1 .

Tabel 1. Frekuensi pernapasan ayam jantan tipe medium

\begin{tabular}{cccc}
\hline \multirow{2}{*}{ Ulangan } & \multicolumn{3}{c}{ Perlakuan } \\
\cline { 2 - 4 } & R1 & R2 & R3 \\
\hline \multirow{2}{*}{1} & 53,60 & 52,80 & 50,80 \\
2 & 54,80 & 56,80 & 54,80 \\
3 & 51,20 & 49,60 & 52,00 \\
4 & 51,60 & 60,40 & 51,60 \\
5 & 46,40 & 59,20 & 66,80 \\
6 & 52,80 & 52,80 & 46,80 \\
\hline Jumlah & 310,40 & 331,60 & 322,80 \\
\hline Rata-rata & 51,73 & 55,27 & 53,80 \\
\hline
\end{tabular}

Keterangan:

R1: Persentase pemberian ransum $30 \%$ siang dan $70 \%$ malam

R2: Persentase pemberian ransum 50\% siang dan 50\% malam

R3: Persentase pemberian ransum $70 \%$ siang dan $30 \%$ malam

Hasil penelitian (Tabel 1) menunjukkan frekuensi pernapasan pada ayam dengan persentase pemberian ransum 30\% siang dan 70\% malam hari frekuensi pernapasannya sebesar $51,73 \mathrm{kali} /$ menit; persentase ransum $50 \%$ siang dan 50\% malam frekuensi pernapasannya sebesar 55, $27 \mathrm{kali} /$ menit; dan persentase ransum 70\% siang dan $30 \%$ malam sebesar $53,80 \mathrm{kali} /$ menit. Hasil analisis ragam menunjukkan bahwa pengaruh metode pemberian ransum pada siang dan malam hari di kandang postal tidak berbeda nyata $(\mathrm{P}>0,05)$ terhadap frekuensi pernapasan. Hal ini diduga karena metode persentase pemberian ransum siang dan malam hari yang diberikan tidak mempengaruhi frekuensi pernapasan ayam jantan tipe medium. Rata-rata pernapasan dalam penelitian ini tergolong tinggi. Menurut Abioja et al. (2012), frekuensi pernapasan ayam pada kondisi normal sebanyak 20-30 kali per menit. Menurut Hapsari et al. (2016), saat temperatur $30,2^{\circ} \mathrm{C}$ dan kelembaban $89,0 \%$ frekuensi pernafasan meningkat menjadi 39 kali per menit dan akan meningkat seiring laju suhu lingkungan dan kelembaban. Pada penelitian ini perlakuan diberikan $30 \%$ siang dan $70 \%$ malam tidak memberikan perbedaan yang nyata terhadap frekuensi pernapasan ayam dibandingkan dengan perlakuan lain yang diberikan ransum lebih banyak di siang hari. Hal ini karena pengaruh frekuensi pernapasan diduga lebih disebabkan oleh suhu lingkungan yang tinggi pada kandang postal yang beralaskan litter daripada pengaruh panas hasil metabolisme.

Peningkatan frekuensi pernapasan diduga disebabkan oleh kondisi suhu lingkungan yang mulai panas. Fati (1991) menyatakan bahwa suhu lingkungan merupakan salah satu faktor yang mempengaruhi konsumsi ransum. Bila suhu tinggi, ayam akan mengonsumsi air lebih banyak, akibatnya nafsu makan menurun. Sebaliknya, pada suhu yang rendah (sejuk hari) ayam akan makan dengan frekuensi jauh lebih banyak sehingga konversi ransum akan baik (Amrullah, 2003).

Frekuensi pernapasan yang tidak berbeda nyata dengan pemberian persentase ransum yang berbeda antara siang dan malam hari, disebabkan frekuensi pernapasan lebih dipengaruhi oleh suhu lingkungan karena semua ayam mendapatkan suhu lingkungan yang sama. Walaupun ayam diberikan ransum sedikit pada siang hari yang suhu nya tinggi ayam tetap mengalami cekaman panas karena tingginya suhu lingkungan. Demikian juga ayam diberikan ransum dengan persentase $70 \%$ pada siang hari juga mengalami cekaman panas yang tinggi karena suhu lingkungan yang tinggi. Suhu kandang pada waktu siang hari yaitu $30,51^{\circ} \mathrm{C}$ menyebabkan ayam panting dan membuat frekuensi pernapasan meningkat. Sedangkan suhu nyaman untuk ayam jantan tipe medium berkisar antara $25-28^{\circ} \mathrm{C}$ (Medion, 2012). Menurut Abioja et al. (2012), frekuensi pernapasan ayam pada kondisi normal sebanyak 20-30 kali per menit, tetapi saat temperatur $30,2^{\circ} \mathrm{C}$ dan kelembaban $89,0 \%$, frekuensi pernapasan meningkat menjadi $39 \mathrm{kali}$ per menit. Ditambahkan oleh Priyatno (1994), suhu lingkungan normal untuk ayam berkisar antara $21-27^{\circ} \mathrm{C}$.

Pada suhu tinggi ayam berusaha melepaskan panas dalam tubuhnya dengan cara panting. Panting merupakan pembuangan panas tubuh menggunakan proses penguapan air dalam tubuh melalui saluran pernapasan (Fadilah, 2004). Oleh karena itu, frekuensi pernapasan ayam jantan tipe medium meningkat. Hal ini sesuai dengan pendapat Mc Dowell (1972) bahwa suhu lingkungan yang tinggi, maka akan menyebabkan peningkatan denyut jantung dan frekuensi pernapasan. Hasil pada penelitian ini selaras dengan kedua pendapat tersebut bahwa perbedaan 
suhu dan kelembaban udara dapat mempengaruhi frekuensi pernapasan.

Frekuensi pernapasan yang tinggi pada penelitian ini juga disebabkan oleh kelembaban udara yang relatif tinggi. Kelembaban udara pada kandang berkisar antara 55,23-79,89\%. Menurut North dan Bell (1990), kelembaban udara yang ideal untuk ayam jantan tipe medium adalah $60-70 \%$. Kelembaban yang tinggi dapat menimbulkan gangguan pernapasan pada ayam. Hal ini sesuai dengan pendapat Fadilah (2004), jika kelembaban terlalu tinggi maka dapat mengganggu saluran pernapasan karena tingginya air di udara.

Suasana pada litter yang pengap dan bau pada kandang mengindikasikan adanya kandungan amonia. Hal ini karena pada kandang litter feses tertinggal pada hamparan litter sehingga sirkulasi udara yang kurang baik, suasana lebih pengap dan bau yang menyengat. Kondisi ini menyebabkan kelembaban udara dalam kandang tinggi. Kondisi ini juga dapat menyebabkan frekuensi pernapasan meningkat akibat meningkatnya amonia dalam kandang. Menurut North and Bell (1990), kondisi internal litter akan mempunyai efek terhadap kelembaban dan suhu di luar maupun di dalam kandang, konsumsi air, stres ayam, penyakit dan perkembangan jamur di dalam kandang. Hal ini sesuai dengan pendapat Fadilah (2004), jika kelembaban terlalu tinggi maka dapat mengganggu saluran pernapasan karena tingginya air di udara.

\section{Pengaruh Perlakuan terhadap Suhu Rektal Ayam Jantan Tipe Medium}

Hasil penelitian menunjukkan bahwa ratarata pengaruh perlakuan terhadap suhu rektal pada masing-masing perlakuan dapat dilihat pada Tabel 2. Hasil penelitian ini menunjukkan suhu rektal pada ayam yang mendapat perlakuan persentase pemberian ransum $30 \%$ siang hari dan $70 \%$ malam hari suhu rektalnya yaitu sebesar $41,16^{\circ} \mathrm{C}$; perlakuan persentase pemberian ransum $50 \%$ siang hari dan $50 \%$ malam hari suhu rektalnya sebesar $41,16^{\circ} \mathrm{C}$; dan perlakuan persentase pemberian ransum $70 \%$ siang hari dan $30 \%$ malam hari suhu rektalnya sebesar $41,13^{\circ} \mathrm{C}$. Berdasarkan hasil analisis ragam menunjukkan bahwa pengaruh metode pemberian ransum pada siang dan malam hari tidak berbeda nyata $(\mathrm{P}>0,05)$ terhadap suhu rektal ayam jantan tipe medium. Hal ini disebabkan oleh perlakuan persentase ransum yang banyak diberikan pada siang hari atau malam hari tidak mempengaruhi suhu rektal, karena suhu lingkungan di dalam kandang postal panas. Panas yang berasal dari litter juga panas dari metabolisme tubuh memberikan cekaman yang sama terhadap ayam sehingga suhu rektal ayam menjadi tidak berbeda nyata. Kusnadi dan Rahim (2009) menyatakan bahwa ayam broiler yang menghadapi suhu tinggi akan terjadi penimbunan panas dalam tubuhnya, untuk mengurangi suhu yang tinggi maka ternak berusaha mengeluarkan panasnya.

Tabel 2. Suhu rektal ayam jantan tipe medium

\begin{tabular}{cccc}
\hline \multirow{3}{*}{ Ulangan } & \multicolumn{3}{c}{ Perlakuan } \\
\cline { 2 - 4 } & $\mathrm{R} 1$ & $\mathrm{R} 2$ & $\mathrm{R} 3$ \\
\hline & $---------\left({ }^{\circ} \mathrm{C}\right)--------$ \\
1 & 41,02 & 41,00 & 41,24 \\
2 & 41,28 & 41,4 & 41,04 \\
3 & 40,98 & 41,06 & 40,90 \\
4 & 41,02 & 41,50 & 41,14 \\
5 & 41,50 & 40,98 & 41,36 \\
6 & 41,16 & 41,04 & 41,08 \\
\hline Jumlah & 246,96 & 246,98 & 246,76 \\
\hline Rata- & 41,16 & 41,16 & 41,13 \\
rata & &
\end{tabular}

Keterangan:

R1: Persentase pemberian ransum 30\% siang dan $70 \%$ malam

R2: Persentase pemberian ransum 50\% siang dan 50\% malam

R3: Persentase pemberian ransum $70 \%$ siang dan $30 \%$ malam.

Rata-rata suhu harian dalam kandang postal saat penelitian yaitu $27,36^{\circ} \mathrm{C}$ dengan kisaran $23,83-30,51^{\circ} \mathrm{C}$ (Tabel 2). Priyatno (1994) menyatakan bahwa suhu lingkungan normal untuk ayam berkisar antara $21-27^{\circ} \mathrm{C}$. Pada suhu yang tinggi ayam akan mengurangi konsumsi ransum untuk mengurangi suhu panas dalam tubuhnya, dan ayam meningkatkan konsumsi air minum untuk menstabilkan suhu tubuhnya. Hal ini sesuai dengan Fadilah (2004), bahwa suhu yang tinggi mengakibatkan ayam mudah mengalami dehidrasi sehingga menyebabkan peningkatan konsumsi air minum yang menyebabkan konsumsi ransum menurun.

Suhu lingkungan tinggi akan mempengaruhi tingkah laku ternak serta fungsi beberapa organ tubuh, seperti jantung dan alat pernapasan serta meningkatkan suhu rektal (Sohail et al. 2010). Suhu rektal dapat digunakan sebagai salah satu indikator respon fisiologi ayam. Hasil rata-rata suhu rektal pada penelitian ini termasuk pada kisaran normal, sesuai dengan pendapat Frandson (1992), suhu rektal normal berkisar $40,6-43,0^{\circ} \mathrm{C}$. Kemampuan adaptasi ayam terhadap panas juga sangat mempengaruhi respon 
fisiologis ayam. Pada penelitian ini ayam jantan tipe medium diduga memiliki kemampuan adaptasi terhadap panas yang baik sehingga meskipun berada pada perlakuan pemberian persentase ransum yang berbeda antara siang dan malam, ayam tetap dapat mempertahankan suhu tubuhnya dalam keadaan normal. Hal ini disebabkan oleh saat ayam menghadapi cekaman panas, tubuh beradaptasi melalui proses termoregulasi, sehingga panas yang dilepaskan sebanding dengan panas yang diterima dan yang dibentuk dalam tubuh (Lin et al., 2005). Selain itu, ayam mampu menghadapi cekaman panas dengan meningkatkan frekuensi napas.

\section{Pengaruh Perlakuan terhadap Frekuensi Denyut Jantung Ayam Jantan Tipe Medium}

Hasil penelitian menunjukkan bahwa rata-rata frekuensi denyut jantung ayam jantan tipe medium pada perlakuan dapat dilihat pada Tabel 3.

Tabel 3. Frekuensi denyut jantung ayam jantan tipe medium

\begin{tabular}{cccc}
\hline \multirow{2}{*}{ Ulangan } & \multicolumn{3}{c}{ Perlakuan } \\
\cline { 2 - 4 } & R1 & R2 & R3 \\
\hline & 398,8 & 433,2 & 434,0 \\
2 & 428,4 & 445,2 & 427,6 \\
3 & 421,6 & 404,4 & 431,6 \\
4 & 430,0 & 432,4 & 437,6 \\
5 & 412,2 & 454,4 & 426,4 \\
6 & 436,4 & 438,8 & 434,8 \\
\hline Jumlah & $2.527,4$ & $2.608,4$ & 2.592 \\
\hline Rata-rata & 421,2 & 434,7 & 432 \\
\hline
\end{tabular}

Keterangan:

R1: Persentase pemberian ransum 30\% siang dan 70\% malam

R2: Persentase pemberian ransum 50\% siang dan 50\% malam

R3: Persentase pemberian ransum $70 \%$ siang dan $30 \%$ malam

Hasil penelitian ini menunjukkan frekuensi denyut jantung pada ayam yang mendapat perlakuan persentase pemberian ransum $30 \%$ siang hari dan $70 \%$ malam hari sebesar $421,2 \mathrm{kali} / \mathrm{menit}$; persentase pemberian ransum 50\% siang hari dan 50\% malam hari sebesar 434,7 kali/menit; dan persentase pemberian ransum $70 \%$ siang dan 30\% malam sebesar $432 \mathrm{kali} /$ menit. Berdasarkan perhitungan analisis ragam menunjukkan bahwa pengaruh metode pemberian ransum pada siang dan malam hari tidak berbeda nyata $(\mathrm{P}>0,05)$ terhadap frekuensi denyut jantung ayam jantan tipe medium. Pemberian persentase ransum siang dan malam tidak mempengaruhi frekuensi detak jantung ayam. Hal ini mungkin disebabkan oleh panas hasil metabolisme ayam yang diberi ransum siang dan malam hari tidak berbeda sehingga frekuensi denyut jantung tidak berbeda nyata.

Hasil penelitian menunjukkan frekuensi denyut jantung masih dalam kisaran normal. Frandson (1992) menyatakan bahwa kisaran normal frekuensi denyut jantung pada ayam berkisar antara 250-470 kali/menit. Frekuensi denyut jantung dalam kisaran normal dipengaruhi oleh berbagai faktor, yaitu temperatur lingkungan, ransum, aktivitas latihan otot (Zurriyati dan Dahono, 2013). Hasil tersebut menunjukkan bahwa faktor-faktor yang mempengaruhi frekuensi denyut jantung pada ayam jantan tipe medium tidak dipengaruhi oleh pemberian ransum pada siang dan malam hari. Hal tersebut juga dapat dilihat dari temperatur rektal yang masih dalam kisaran normal.

Frekuensi denyut jantung yang tidak berbeda nyata saat penelitian juga disebabkan oleh suhu dan kelembaban pada kandang yang diterima ayam sama. Pada penelitian ini ayam jantan tipe medium diduga memiliki kemampuan adaptasi terhadap panas yang baik sehingga meskipun berada pada perlakuan pemberian persentase ransum yang berbeda antara siang dan malam, ayam tetap dapat mempertahankan suhu tubuhnya dalam keadaan normal. Hal ini disebabkan pada saat ayam menghadapi cekaman panas, tubuh beradaptasi melalui proses thermoregulasi, sehingga panas yang dilepaskan sebanding dengan panas yang diterima dan yang dibentuk dalam tubuh (Lin et al., 2005). Selain itu, ayam mampu menghadapi cekaman panas dengan meningkatkan frekuensi napas.

\section{SIMPULAN DAN SARAN}

\section{Simpulan}

Berdasarkan hasil penelitian dapat disimpulkan bahwa

(1). Metode persentase pemberian ransum pada siang dan malam hari tidak berpengaruh nyata $(\mathrm{P}>0,5)$ terhadap frekuensi pernapasan, suhu rektal dan fekuensi denyut jantung

(2) Metode persentase pemberian ransum tidak mendapatkan hasil terbaik terhadap frekuensi pernapasan, suhu rektal dan frekuensi denyut jantung. 


\section{Saran}

Perlu dilakukan penelitian lebih lanjut tentang pengaruh metode pemberian ransum siang dan malam hari terhadap respon fisiologis ayam pada kandang yang berbeda menggunakan metode pembagian waktu yang berbeda, sehingga diketahui pengaruh pembagian waktu terhadap respon fisiologis ayam jantan tipe medium.

\section{DAFTAR PUSTAKA}

Abioja, M. O., K. B. Ogundimu, T. E. Akibo, K. E. Odukoya, O. O. Ajiboya, J. A. Abiona, T. J. Williams, E. O. Oke, dan O. O. Osinowo, 2012, Growth, Mineral Deposition, Responses of Broiler Chickens Offered Honey in Drinking Water During Hot-Dry Season. Poultry Science 82: 2701-2861.

Aksi Agraris Kansius (AAK), 2003, Beternak Ayam Pedaging Cetakan ke-18, Kanisus Yogyakarta.

Amrullah, I. K., 2003, Nutrisi Ayam Petelur, Lembaga Satu Gunung Budi. Bogor.

Fadilah, R., 2004, Kunci Sukses Beternak Ayam Broiler di Daerah Tropis, Agromedia Pustaka. Jakarta.

Fati, N., 1991, Pengaruh Beda Ketinggian Tempat dan Luas Kandang terhadap Laju Pertumbuhan Ayam Broiler, Skripsi, Fakultas Peternakan Universitas Andalas. Padang.

Frandson, R. D., 1992, Anatomi dan Fisiologi Ternak, Edisi ke-4, Gadjah Mada Press. Yogyakarta.

Hapsari, I.N., P.E. Santosa, dan Riyanti, 2016, Perbedaan Sistem Brooding Konvensional dan Sistem Brooding Thermos terhadap Respon Fisiologis Broiler. J. Ilmiah Peternakan Terpadu. 4(3): 237- 243.

Hartono, M., S. Suharyati, dan P.E. Santosa, 2002, Dasar Fisiologi Ternak. Buku Ajar Jurusan Peternakan, Fakultas Pertanian, Universitas Lampung. Bandar Lampung.

Kusnadi E, Rahim F., 2009, Performa dan Kandungan Hormone Triiodotironin Plasma Ayam Broiler akibat Pengaruh Cekaman Panas di Daerah Tropik. Media Peternak. 32:155-162.
Lin, H., H. F. Zhang, R. Du, X. H. Gu, Z. Y. Zhang, J. Buyse and E. Decuypere, 2005, Thermoregulation Responses of Broiler Chickens to Humidity at Different Ambient Temperatures. II. Four Weeks of Age. Poultry Science. 84:1173-1178.

Mc. Dowell, R. E. Perdue, 197, The Evironment Versus Man and His Animal. In: Cole, H. H and M. Ronning (Eds). Animal Agriculture. W. H. Feeman and Company. San Fransisco. Italia.

Medion, 2012, http://ayamkampung. org/artikel/penyakit-pernapas an-yang-takpernah-tuntas. html. Diakses pada 06 Februari 2020.

North, M.O. and D.D. Bell., 1990, Commercial Chicken Production Manual, 4th Edition, Publishing by Chapman and Hall One. New York.

Priyatno, 1994, Membuat Kandang Ayam, Cetakan ke-8, Penebar Swadaya, Jakarta.

Riyanti, 1995, Pengaruh Berbagai Imbangan Energi Protein Ransum terhadap Performans Ayam Jantan Petelur Tipe Medium, Prosiding Seminar Nasional Sains dan Teknologi Peternakan, Balai Penelitian Ternak. Ciawi. Bogor.

Sohail MU, Ijaz A, Yousaf MS, Ashraf K, Zaneb H, Aleem M, Rehman H., 2010, Alleviation of Cyclic Heat Stress in Broilers by Dietary Supplementation of Mannanoligosaccharide and Lactobacillus-based Probiotic: Dynamics of Cortisol, Thyroid Hormones, Cholesterol, C-reactive Protein, and Humoral Immunity. Poult Sci. 89:19341938.

Yousef, M. K., 1985, Thermoneutral Zone. In: M.K. Yousef (Ed.). Stress Physiology of Livestock. Vol.II. CRC Press, Inc. Boca Raton, Florida. p.68-69.

Zurriyati, Y. dan Dahono, 2013, Respon Fisiologis dan Evaluasi Karkas Ayam Broiler terhadap Suhu Pemeliharaan Dingin, Seminar Nasional Teknologi Peternakan dan Veteriner Tahun 2013, Balai Pengkajian Teknologi Pertanian Riau, Tanjung Pinang 